EGU2020-9042

EGU General Assembly 2020

(c) Author(s) 2020. This work is distributed under

the Creative Commons Attribution 4.0 License.

\title{
Multi-scale and multi-disciplinary investigation of the southwest Portuguese Continental shelf, the MINEPLAT project
}

\author{
Pedro Terrinha ${ }^{1,2}$, Carlos Ribeiro ${ }^{3,4}$, João Noiva ${ }^{1}$, Marcos Rosa ${ }^{1}$, Pedro Brito ${ }^{1}$, Vitor Magalhães ${ }^{1,2}$, \\ Marta Neres ${ }^{1,2}$, Pedro Nogueira ${ }^{3,4}$, Sandra Velez ${ }^{3}$, Ângela Pacheco ${ }^{3}$, Mário Mil-Homens ${ }^{1}$, Mariana \\ Luis $^{3}$, Laura Andrade ${ }^{3}$, André Carvalho ${ }^{3}$, Paula Afonso ${ }^{3}$, and Mariana Silva ${ }^{1}$ \\ ${ }^{1}$ IPMA, Marine Geology, Lisboa, Portugal (pedro.terrinha@ipma.pt) \\ ${ }^{2} \mathrm{IDL}$, Instituto Dom Luiz, FCUL, Portugal \\ ${ }^{3}$ Dep. Geosciences, Sciences \& Technology School, University of Évora, Portugal \\ ${ }^{4} \mathrm{ICT}$, Earth Sciences Institute, University of Évora, Portugal
}

The MINEPLAT project (Assessment of the mineral resources potential in the continental shelf of Alentejo and of the environmental conditions caused by the tectonic uplift in the PlioceneQuaternary) allowed acquisition of $1700 \mathrm{~km}$ of ultra- high resolution seismic profiles, and full coverage of multibeam bathymetry and acoustic backscatter of $1450 \mathrm{~km}^{2}$ and $1940 \mathrm{~km}$ of magnetic data of the Alentejo continental shelf, SW Portugal. 270 sediment samples were collected (Smyth-Macyntire dredges and multicores) and processed for sediment, geochemical and mineralogical analyses (granulometry, Xray diffractometry, major and trace metals analysis).

The wealth of data is meeting its full processing phase. Preliminary interpretation of the large dataset has already allowed to understand various novel contributions: i) identification of various sea level stand stills in Pliocene-Quaternary times; ii) drainage network during low stand sea levels; iii) grainsize dependency on submarine relief and inherited morphology from low stand periods; iv) eustatic, oceanographic, fluvial and depth dependency of the post-alpine orogeny deposits of Pliocene-Quaternary age; v) location of deposits with high-quality sand for beach nourishment; and vi) identification of submarine harbor waste disposal sites and their environmental impact and dispersal; vii) high resolution mapping of magnetic anomalies related with magmatic events that can be source of heavy minerals.

The authors would like to acknowledge the FCT financial support through project UIDB/50019/2020 - IDL and MINEPLAT project ALT20-03-0145-FEDER-000013 